\title{
PEMANFAATAN TEPUNG TALAS DAN FORMULA TEMPE SEBAGAI BAHAN PEMBUAT COOKIES
}

\author{
The Use of Taras Flour and Formula Tempe as a Cookies Maker
}

\author{
Nur Asnah Sitohang ${ }^{1}$, Farida Linda Sari Siregar ${ }^{2}$ \\ ${ }^{1}$ Dosen Fakultas Keperawatan Universitas Sumatera Utara \\ Email.nur75asnah@yahoo.co.id \\ ${ }^{2}$ Dosen Fakultas Keperawatan Universitas Sumatera Utara \\ Email: farida.linda@ymail.com
}

\begin{abstract}
Abstrak
Asupan makanan yang bergizi amat penting untuk balita agar bisa tumbuh dan berkembang dengan optimal. Salah satu bahan pangan sumber energi (makanan berpati) non beras adalah umbi talas bogor. Umbi talas bogor dimanfaatkan sebagai bahan industri pangan dapat diolah menjadi tepung talas dan dijadikan menjadi berbagai hasil olahan misalnya roti kering, bakso, dan lain-lain. Sedangkan sebagai sumber protein nabati dari kacang-kacangan adalah kacang kedelai yang sudah dikonsumsi masyarakat antara lain tempe, kecap, dan lain-lain. Metode pengabdian masyarakat yang digunakan adalah pendidikan, pelatihan pembuatan cookies berdasar bahan tepung talas dan formula tempe, deteksi dini dan intervensi dini penyimpangan tumbuh kembang anak dan pendampingan. Pengabdian masyarakat ini bertujuan memberdayakan ibu balita dalam memanfaatkan tepung talas dan formula tempe guna untuk mengembangkan penganekaragaman pangan dan menambah pengetahuan tepat guna serta meningkatkan status gizi balita. Pengabdian masyarakat ini dilakukan di Posyandu Mawar Klinik Bersalin Babar Sari dan Posyandu Anggrek 1 Praktek Bidan Marinta Ulina di Desa Baru .Kec. Pancur Batu .Deli Serdang. Hasil pengabdian kepada masyarakat ini adalah ibu-ibu mampu membuat tepung talas, formula tempe dan mengolahnya menjadi cookies dengan baik serta meningkatnya status gizi balita. Oleh sebab itu disarankan kepada ibu agar giat dalam membuat cookies dan menjadikannya makanan tambahan bagi balita.
\end{abstract}

Kata Kunci: Cookies, Tepung Talas, Formula Tempe, Status Gizi, Balita

\begin{abstract}
Intake of nutritious foods is very important for pre schools in order to grow and develop optimally. One of the food sources of energy (non starch food) is the tuber of taro bogor. Bulbs taro bogor used as food industry materials can be processed into flour taro and made into various processed products such as dry bread, meatballs, and others. While as a source of vegetable protein from beans are soybeans that have been consumed by the community, among others, tempe, soy sauce, and others. Community service method used is education, training of cookie making based on taro flour and tempe formula, early detection and early intervention deviation of child growth and mentoring. This community service aims to empower the mother of pre school age in utilizing taro flour and tempe formula in order to develop food diversity and increase the appropriate knowledge and improve the nutritional status of children. This community service is done at Posyandu Klinik Bersalin Mawar Babar Sari and Posyandu Anggrek 1 Klinik Bersalin Marinta Ulina in Desa Baru, Pancur Batu ,Deli Serdang. The result of this dedication to the community is that mothers are able to make taro flour, tempe formula and process it into cookies well and increase the nutritional status of children. It is therefore advisable for the mother to be diligent in making cookies and making it an additional food for pre schools.
\end{abstract}

Keywords: Cookies, Flour Taro, Formula Tempe, Nutritional Status, Pre school 


\section{PENDAHULUAN}

Kebutuhan pangan semakin meningkat dengan bertambahnya jumlah penduduk. Berbagai jenis pangan diproduksi meningkatkan kuantitas dan kualitasnya untuk memenuhi kebutuhan pangan masyarakat. Selain dengan meningkatkan jumlahnya, pemenuhan kebutuhan pangan juga dapat dilakukan dengan mengoptimalkan penggunaan sumber bahan pangan yang beraneka ragam. Hal ini dilakukan upaya diversifikasi pangan dengan memanfaatkan sumber daya pangan lokal. Potensi bahan pangan daerah yang bersumber dari umbi-umbian seperti talas dan kacangkacangan adalah komoditas pertanian Indonesia yang dapat dimanfaatkan sebagai sumber bahan pangan (Mayang dan Amindyajati, 2007).

Menurut Rukmana (2006), salah satu bahan pangan sumber energi (makanan berpati) non beras adalah umbi talas bogor (Colocasia esculenta (L.) Schott). Umbi talas bogor dimanfaatkan sebagai bahan industri pangan dapat diolah menjadi tepung talas dan dijadikan menjadi berbagai hasil olahan misalnya roti kering, bakso, mie basah, dan lain - lain. Sedangkan sebagai sumber protein nabati dari kacang-kacangan adalah kacang kedelai yang sudah dikonsumsi masyarakat antara lain tempe, kecap, tauco, susu kedelai, dan lain-lain.

Tempe pada umumnya dikenal masyarakat Indonesia yaitu tempe dari kacang kedelai berwarna kuning, bentuknya padat dan memiliki sesuatu yang komplek, dan tertutup oleh miselium berwarna putih yang harganya relatif murah. Produk tempe perlu dikembangkan dan divariasikan dengan mengolah menjadi formula tempe yang tujuannya untuk penganekaragaman pangan dan meningkatkan kualitas mutu makanan khususnya meningkatkan zat gizi suatu produk makanan misalnya formula makanan bayi, formula untuk anak balita formula untuk usia lanjut dan biskuit nama umumnya adalah Cookies. (Rukmana,2006)

Kabupaten Deli Serdang salah satu daerah penghasil talas. Talas ini kurang populer dibandingkan ubi kayu dan ubi jalar akibatnya produk talas Bogor yang beredar di masyarakat kurang bervariasi. Sedangkan sebagai sumber protein nabati adalah kacang kedelai yang sudah dikenal masyarakat yang dapat diolah menjadi berbagai jenis olahan makanan. Produk tempe perlu dikembangkan dan divariasikan dengan mengolah menjadi formula tempe yang tujuannya untuk penganekaragaman pangan dan meningkatkan kualitas mutu makanan khususnya meningkatkan zat gizi suatu produk makanan misalnya formula untuk anak balita biskuit dan nama umumnya adalah Cookies.

Pada tahun 2012, dari 193.881 balita yang ada di kota Medan, terdapat 871 anak $(3,41$ $\%)$ status gizi kurang dan mengalami gangguan perkembangan meragukan berdasarkan KPSP sebanyak 22 anak (0.09 \%). Di Kecamatan Pancur Batu khususnya Desa baru terdapat 800 balita dan 5 posyandu. Terdapat 56 anak status gizi kurang dan 12 balita mengalami gangguan perkembangan. Tahun 2015 program MGGs dicanangkan secara nasional bahwa prevalensi status gizi balita kurang dan buruk harus turun minimal 2.4\%. Oleh sebab itu pengabdian masyarakat ini sangat penting dilakukan untuk menyukseskan program pemerintah tersebut.

Pengabdian masyarakat ini bertujuan memberdayakan ibu balita dalam memanfaatkan tepung talas dan formula tempe guna untuk mengembangkan penganekaragaman pangan dan menambah pengetahuan tepat guna serta meningkatkan status gizi balita.

\section{METODE}

Metode pengabdian kepada masyarakat yang dilakukan adalah memberikan pendidikan, pelatihan dan pendampingan pembuatan tepung talas dan formula tempe serta pembuatan cookies. dan intervensi dini penyimpangan tumbuh kembang anak dan pendampingan. Pengabdian masyarakat ini dilakukan di Posyandu Mawar Klinik Bersalin Babar Sari dengan jumlah ibu yang memiliki balita ada 10 orang dan Posyandu Anggrek 1 Praktek Bidan Marinta Ulina di Desa Baru .Kec. Pancur Batu .Deli Serdang dengan jumlah ibu yang memiliki balita ada 15 orang.

\section{HASIL DAN PEMBAHASAN}

Kegiatan pengabdian masyarakat ini diawali dengan tahap persetujuan dilakukannya kegiatan ini oleh Posyandu Mawar Klinik Bersalin Babar Sari dan Posyandu Anggrek 1 Praktek Bidan Marinta Ulina di Desa Baru .Kec. Pancur Batu.Deli Serdang tanggal 8 Maret 2016.

Setelah dilakukan kesepakatan, maka pada tanggal 11 sampai dan 13 April 2016 dilaksanakan kegiatan penyuluhan dan pelatihan pembuatan tepung talas kepada ibu balita di Posyandu Mawar Klinik Bersalin Babar Sari dan Posyandu Anggrek 1 Praktek Bidan Marinta Ulina di Desa Baru.Kec.Pancur Batu Deli Serdang. Untuk mempermudah pemahaman 
ibu balita dalam pembuatan tepung talas,formula tempe dan cookies diberikan buku. Pada tanggal 18 dan 21 April 2016 dilaksanakan kegiatan penyuluhan dan pelatihan pembuatan formula tempe.Tanggal 25 sampai dan 28 April dilakukan pelatihan pembuatan cookies. Semua ibu balita diberi kesempatan melakukan membuat cookies sampai mahir. Tim pengabdian juga membagikan buku cara pembuatan tepung talas, formula tempe dan cookies.

Pada tanggal 29-30 Agustus 2016 dan tanggal 9-10 september 2016 tim pengabdian memberikan pendidikan dan pelatihan deteksi dini tumbuh kembang anak. Deteksi dini tumbuh kembang adalah kegiatan atau pemeriksaan untuk menemukan secara dini adanya penyimpangan tumbuh kembang pada balita dan anak. Kemudian tim pengabdian membagikan buku pemantauan tumbuh kembang balita.

Pelatihan yang dilakukan bagi ibu balita dan mendapat respon yang positif. Ibu balita tersebut dapat mengikuti pelatihan dan bisa membuat tepung talas,formula tempe dan mengolahnya menjadi cookies dengan baik. Ibu balita bersedia membuat kembali dan menjadikan makanan tambahan bagi balitanya guna memenuhi kebutuhan gizi balita tersebut serta adanya peningkatan status kesehatan gizi anak usia balita secara optimal. Ibu-ibu mampu melakukan deteksi secara dini adanya penyimpangan pertumbuhan (status gizi kurang atau buruk), penyimpangan perkembangan (gangguan perkembangan anak/keterlambatan).

Pemanfaatan tepung talas sebagai bahan baku dalam pembuatan cookies dapat dikombinasikan dengan tepung formula tempe yang bersumber dari bahan lain sehingga menjadi tepung komposit. Kombinasi tersebut dilakukan untuk melengkapi kandungan gizi tepung talas sehingga memberikan nilai tambah untuk bahan tersebut.

Kandungan gizi talas tergolong rendah terdapat dalam 100 gram talas yaitu 1,5 gram protein dan karbohidrat 28,2 gram oleh karena itu diperlukan bahan lain yang digunakan untuk menambah kekurangan dari umbi talas antara lain bahan yang digunakan adalah tepung formula tempe yang akan divariasikan dalam pembuatan cookies.

Penelitian yang dilakukan Bakara dkk (2013) dengan tujuan menilai mutu fisik Cookies yang diolah dari variasi formulasi tepung talas
(Colocasia esculenta (L.) Schott) dan formula tempe secara organoleptik, meliputi : warna, tekstur, rasa, dan aroma diperoleh hasil penilaian mutu fisik cookies yaitu tepung talas formula tempe yang paling disukai panelis adalah perlakuan $\mathrm{C}$ dengan perbandingan 50:50 (tepung talas : formula tempe) meliputi dari segi warna, tekstur, rasa, dan aroma menghasilkan cookies tepung talas formula tempe warna kuning kecoklatan, tekstur renyah, rasa manis dan gurih dan aroma yang normal tidak bau tengik, dan hasil analisis pada mutu kimia cookies tepung talas formula tempe adalah 4,21gr kadar air, 3,48gr kadar abu, 21,78gr kadar lemak, 6,60 kadar protein,63,80gr kadar kahbohidrat dan energi 478,05 kkal/100gr bahwa cookies tepung talas formula tempe dapat dijadikan makanan selingan bagi anak - anak.

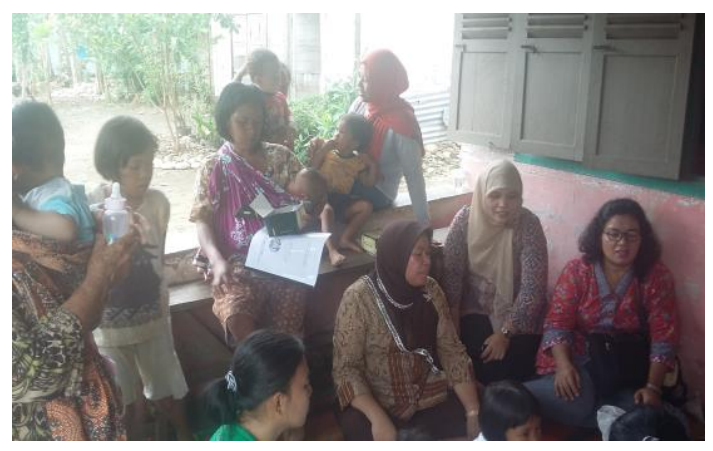

Gbr.1 ibu-ibu peserta pelatihan

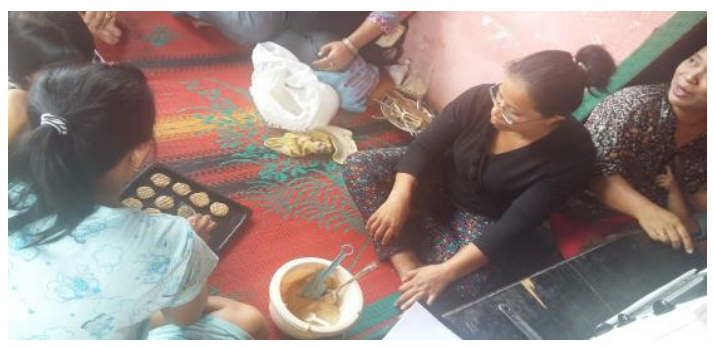

Gbr. 2 Ibu-ibu sedang membuat cookies

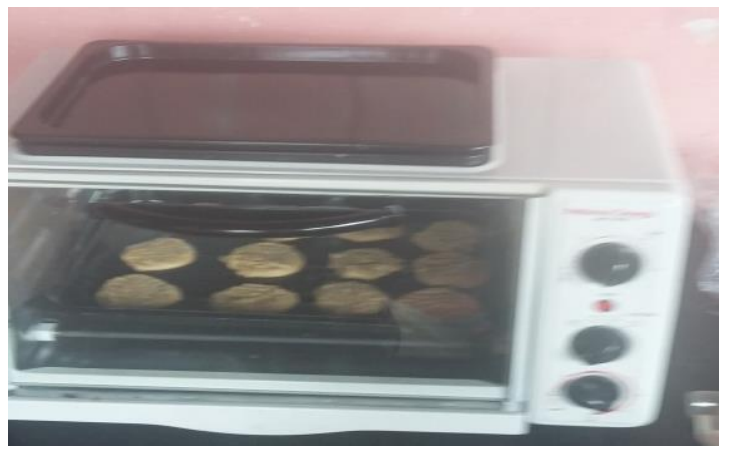

Gbr.3 Cookies sedang dimasak 


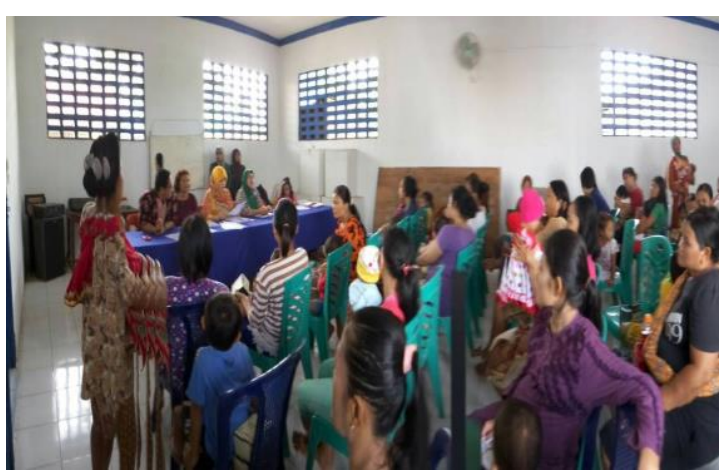

Gbr. 4. Balita dilakukan pemeriksaan pertumbuhan dan perkembangan.

\section{KESIMPULAN}

Kegiatan pengabdian masyarakat berjalan dengan baik dan lancar. Seluruh ibu sudah dapat membuat secara mandiri tepung talas, formula tempe dan cookies. Ibu juga bersedia melanjutkan pembuatan cookies dan memberikan kepada anaknya. Cookies tepung talas dan formula tempe ini terbukti dapat memenuhi gizi balita. Oleh sebab itu disarankan kepada ibu balita agar giat memanfaakan tepung talas dan varietas umbi lokal lainnya serta formula tempe untuk cookies bagi balita.

\section{DAFTAR PUSTAKA}

Bakara, T.L, Rumida, Manalu, M. 2013. Variasi Formulasi Dan Analisis Mutu Fisik Kimia Cookies Dari Tepung Talas (Colocasia Esculenta (L) Schoot) Dan Formula Tempe Untuk Makanan Selingan Pada Anak Sekolah Dasar Inpres 104244 Jatisari Di Lubuk Pakam Tahun 2013. Laporan Penelitian Risbinakes.

Mayang., A. 2007. Formulasi dan Optimasi Produk Biskuit Berbahan Baku Sagu Ubi Jalar dan Kacang Hijau.

Rukmana, R. 2006. Budidaya Talas. Kanisius.Jakarta. 